\title{
Snake pet ownership in the city: A case study in Greater Jakarta, Indonesia
}

\author{
MIRZA D. KUSRINI", SHARON PRATIWI PALESA, BURHANUDDIN MASY'UD \\ Department of Forest Resources and Ecotourism, Faculty of Forestry and Environment, Institut Pertanian Bogor. Jl. Ulin Lingkar Kampus, IPB \\ University Campus Dramaga, Bogor 16680, West Java, Indonesia. Tel./fax.: +62-251-8621947, "email: mirza_kusrini@ yahoo.com.
}

Manuscript received: 9 March 2021. Revision accepted: 18 March 2021.

\begin{abstract}
Kusrini MD, Palesa SP, Masy'ud B. 2021. Snake pet ownership in the city: A case study in Greater Jakarta, Java, Indonesia. Biodiversitas 22: 1790-1798. Snake pets have gained popularity all over the world, including in Indonesia. We conducted an online survey to gather information regarding the characteristics of snake owners, their motivation for keeping snakes, the species owned, and the keepers' knowledge and perception. Google forms were sent to snake owners in the Greater Jakarta area (also known as Jabodetabek), and 69 snake owners responded. Most of the snake owners are in the young adult group (16-25 years) and their motivation to keep snakes comes mostly from them being influenced by their peers, exhibitions and social media. Thirty-nine species of snake from nine families were listed as pets, mostly being snakes that are distributed in Indonesia. Overall, the Pythonidae was the snake family with the most species being selected as pets $(65.7 \%)$, followed by Colubridae (10.7\%) and Viperidae (9.44\%). Most snake owners kept non-venomous snakes (83.3\%), 12\% kept highly venomous snakes, and 4.7\% kept mildly- venomous snakes. Most of the keepers had heard about protected species (91.2\%). However, when asked to write the names of any protected species, $46 \%$ out of 50 people gave incorrect names. The relatively high number of venomous snakes kept (even by those keepers of a young age) indicates the potential risk of envenomation. As yet, there is no system for snake owner licensing in Indonesia, thus it is suggested that, because of the increasing popularity of keeping snakes as pets, owners should be registered, licensed, and monitored.
\end{abstract}

Keywords: Captive reptile, ethnoherpetology, ethnozoology, exotic species, wildlife trade

\section{INTRODUCTION}

Keeping pets has become an increasingly popular activity in recent years, especially as it positively impacts health, both physiologically and psychologically, improving social quality and quality of life in general (Lewis et al. 2009; McConnell et al. 2011). Today, domestic pets are not limited to dogs and cats and include various types of wildlife, including reptiles. In recent years, there has been a significant increase in the keeping of reptiles as pets. This can be seen from the quantities of animals in the global reptile trade that has increased in recent decades (Marshal et al. 2020). The European Union was the top global importer of live reptiles for the trade-in reptiles, both as pets and as reptile skins (Engler and ParryJones 2007). The trade-in live reptiles has increased in the past decade, presumably due to the increased demand for the pet trade (Auliya 2003; Auliya et al. 2016). Aside from Europe, the United States is also a major importer of live reptiles for the pet industry (Herrel and van der Mejden 2014).

The tendency to keep reptiles as pets is restricted to developed countries in the north and in developing countries such as Indonesia, where observations on social media show that this trend is growing rapidly. However, until now there has been no research looking into the details of reptile ownership in Indonesia, although some of this information can be accessed from official reports on the trade of reptiles that are being sold as pets. The exact monetary value of the reptile trade in Indonesia compared to trade around the world is not yet known. However, the number of reptiles traded is relatively high, and is not limited to local species. For example, in 2011, 667 individuals from 52 species of reptiles were recorded as being for sale in animal markets in Jakarta, the capital city of Indonesia (Daniel 2011). In Yogyakarta (a city in Central Java), a survey revealed that there were no less than 645 imported reptiles available in markets, animal shops and consumers (Putranto et al. 2016). Research has shown that people with high levels of income in Jakarta are especially interested in keeping animals, including foreign (non-native) species. This is due to several factors, including: high purchasing power, hobbies, and easy access to shops that provide animals (Sinaga 2008; Mardiastuti 2009).

Based on surveys of the reptile trade, two groups of reptiles were being sold in the highest numbers as pets in Indonesia, i.e. Testudinata (turtles) and Serpentes (snakes) (Sinaga 2008; Daniel 2011; Putranto 2016). Despite often being associated with fear in humans, (Polák et al. 2016), a diverse range of snake species was being traded in Jakarta. At least 35 species of snakes were traded, mostly as pets, although some were also sold for consumption or traditional medicine (Situngkir 2009; Daniel 2011). Jakarta's youngsters and teenagers are considered role models for others in Indonesia due to their lifestyles (Sarwono 2013). The increasing exposure of snake keeping in Jakarta as a lifestyle might be followed by others in 
Indonesia. Thus information on snake keepers in Jakarta will provide a reliable snapshot of future snake keepers more generally in other big cities of Indonesia. The aims of this research are to 1) identify demographic characteristics and motivation to keep snakes as pets, and 2) identify the species of snakes kept as pets, along with their origin and type of maintenance, and 3) the extent of knowledge and perception among snake keepers about snake conservation.

\section{MATERIALS AND METHODS}

\section{Study area}

The study area of this research was in the Jakarta metropolitan area or Greater Jakarta (locally known as Jabodetabek, an acronym for Jakarta - Bogor - Depok Tangerang - Bekasi) consists of the national capital Jakarta as the core city, and other satellite cities (Bogor, Depok, Tangerang and Bekasi) (Hasibuan et al. 2014; Rustiadi et al. 2015). It is the most populous area in Indonesia and is the seat of economics and politics in Indonesia (Rustiadi et al. 2015).

\section{Procedures}

There are no data available on the number of snake owners in Indonesia. A convenient sample of snake owners was used in this study. Data were collected using Google Form online questionnaires from March to April 2019, distributed through the member network of Herpetological Society of Indonesia. We explained the background and aims of the study in the introduction of the questionnaire. Although the request was made to snake owners who live in Greater Jakarta, several snake owners from outside Greater Jakarta also filled in the form. A total of 80 completed questionnaires were received, $69(86.25 \%)$ from people that live in Greater Jakarta, and 11 (13.75\%) from people living outside Greater Jakarta (mostly in Java, except for one person who lives in Palembang in South Sumatra); we omitted data from respondents outside Greater Jakarta.

The questionnaire consists of questions that can be grouped into 4 types of information: Firstly, Respondent characteristics and motivation. Information includes gender, city address, age, education, occupation, membership of snake-owner groups, number of years keeping a snake as a pet, ownership of other species of animal, motivation to keep snakes, and monthly expenditure for keeping snakes. Secondly, snakes as pets. Participants were asked to provide information about the snake(s) in their household, including detailed information, including the first species of snake they owned, the current number of snakes owned, the origin of the snake(s), and maintenance details. Snakes kept as pets were then categorized by the presence and level of venom: nonvenomous snakes, mildly-venomous snakes (medium), and high, or highly venomous snakes (Rusli 2016). Thirdly, Conservation knowledge and perceptions, which include listing any species known to be protected by Indonesian law, perceptions regarding the collection of snakes from the wild, and reasons why some species need to be protected.

\section{Data analysis}

Most of the respondents did not write the scientific name(s) of their snake(s), instead of listing them using the local name or trade name. For instance, Malayopython reticulatus could be listed as "sanca batik", "retik" or "sanca retik". Python curtus as "dipong", and Candoia carinata as "mono pohon", etc. Scientific names were then converted from the local/trade names using taxonomic names according to the Reptile Database (Uetz et al. 2017), and we omitted two unknown terms, i.e. hybrid viper and Colubrid. Snakes were also grouped based on the toxicity (to humans) of their venom, thus: non-venomous, mildly venomous and highly venomous (Rusli 2016). The conservation status of each species was checked using the Red List of Threatened Species of the International Union for Conservation of Nature and Natural Resources (IUCN 2018) and the List of Protected Species of Indonesia, based on the Ministry of Environment \& Forestry Regulation Number .20/MENLHK/SETJEN/KUM.1/6/2018.

\section{RESULTS AND DISCUSSION}

\section{Respondent characteristics and motivation}

Most respondents were male $(n=55,79.1 \%)$ and most were in the young adult age group ( $n=58,16-25$ years). A total of $44.9 \%$ were high school graduates/equivalent and $42.0 \%$ were graduates from tertiary institutions. Most of the respondents were categorized as students, although two people worked as elementary school teachers. At least 25 snake-owner groups and community organizations were listed, based on $52.4 \%$ of the respondents who were members of these snake-owner communities (Table 1).

In general, the interest in keeping snakes was mostly triggered by seeing people/peers close to the respondent who were already keeping snakes $(30.4 \%)$, visiting a snake exhibition, social media, and gifts, or a combination of these factors (Table 2). Various reasons were given for keeping snakes, such as for educational activities, or just out of curiosity. Only about a third of the respondents had kept snakes for less than 2 years, the rest having kept snakes for more than 2 years, and some (38.75\%) had kept snakes for more than 5 years. Most of the respondents $(85 \%)$ also kept other animals besides snakes. Forty percent kept only one species of animal, while the rest kept more than one species (Figure 1). Pets included reptiles, mammals, birds, fish and insects, with the number of pets kept being up to seven species of animal. Only a few kept common domestic animals such as dogs and cats. Most of the snake keepers also kept other reptiles, with monitor lizards (13\%), geckos and skinks $(11 \%)$ being the most commonly kept species (Figure 2). 
Table 1. Characteristics of snake owners in Greater Jakarta (2019) based on gender, age class, latest education and occupation
Table 2. Motivation for keeping snakes as pets in Greater Jakarta (2019)

\begin{tabular}{|c|c|c|c|c|c|c|}
\hline Characteristic & Criteria & Number & Percentage & Motivation & $\mathbf{N}$ & $\%$ \\
\hline \multirow{2}{*}{ Gender } & Male & 55 & $\frac{(70)}{79.71}$ & Close person (= friend or family member) & 21 & 30.4 \\
\hline & Female & 14 & 20.29 & Close person and exhibition & 3 & 4.3 \\
\hline Age Group & $16-20$ & 18 & 26.09 & Close person, exhibition and social media & 3 & 4.3 \\
\hline \multirow[t]{5}{*}{ (Year) } & $21-25$ & 40 & 57.97 & Social media & 2 & 2.9 \\
\hline & $26-30$ & 5 & 7.25 & Social media and gift & 2 & 2.9 \\
\hline & $31-35$ & 3 & 4.35 & Social media and close person & 1 & 1.4 \\
\hline & $36-40$ & 2 & 2.90 & Social media and exhibition & 5 & 7.2 \\
\hline & $>41$ & 1 & 1.45 & Exhibition & 3 & 4.3 \\
\hline Last & Grade $7-9$ or equivalent & & & Gift & 4 & 5.8 \\
\hline \multirow{4}{*}{ education } & & 5 & 7.25 & Other reasons & & 36.2 \\
\hline & Grade $10-12$ or & 31 & 4403 & "Cool” animal (exotic) & 9 & 13.0 \\
\hline & equivalent & & 44.93 & Hobby & $\begin{array}{l}9 \\
3\end{array}$ & $\begin{array}{c}13.0 \\
4.3\end{array}$ \\
\hline & $\begin{array}{l}\text { Undergraduate } \\
\text { Postgraduate }\end{array}$ & 29 & $\begin{array}{c}42.03 \\
5.80\end{array}$ & No reason & 1 & 1.4 \\
\hline \multirow{7}{*}{ Occupation } & Freelance & $\begin{array}{l}4 \\
6\end{array}$ & $\begin{array}{l}5.80 \\
8.70\end{array}$ & Easy to maintain & 2 & 2.9 \\
\hline & Teacher & 2 & 2.90 & Rescued animal (snake found in urban areas and then & 1 & 1.4 \\
\hline & Student & 28 & 40.58 & "rescued" from being killed by residents) & & \\
\hline & GovernmentEmployee & 3 & 4.35 & & & \\
\hline & Private sector & 17 & 24.64 & & & \\
\hline & Unemployed & 3 & 4.35 & & & \\
\hline & Entrepreneur & 10 & 14.49 & & & \\
\hline
\end{tabular}

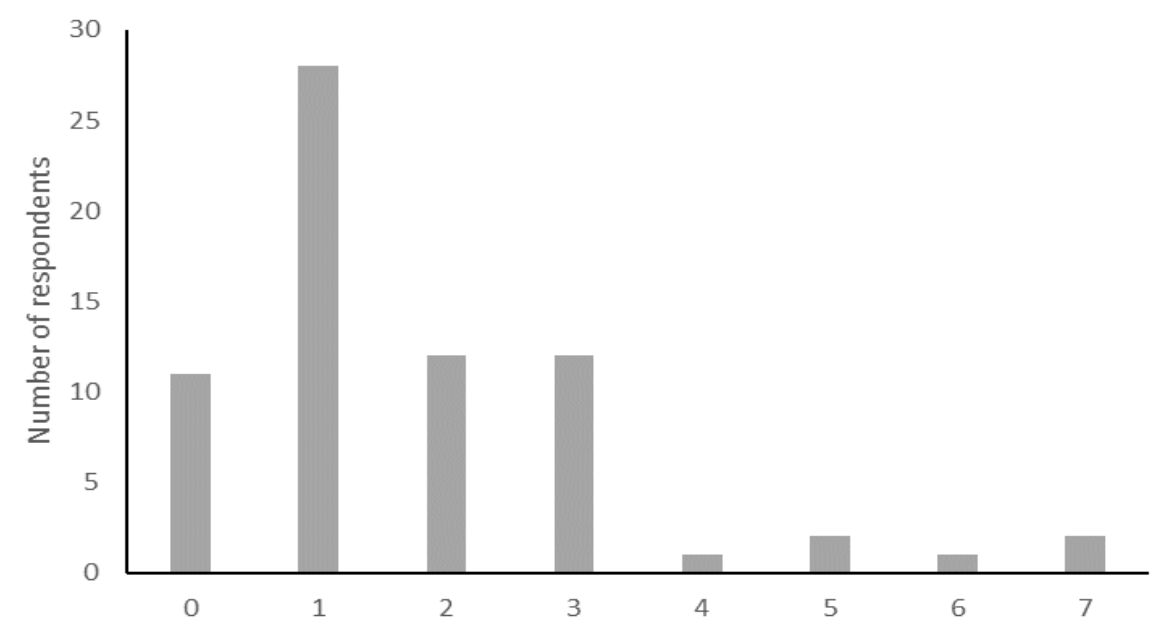

Figure 1. Number of pet species other than snakes being kept by respondents in Greater Jakarta (2019)

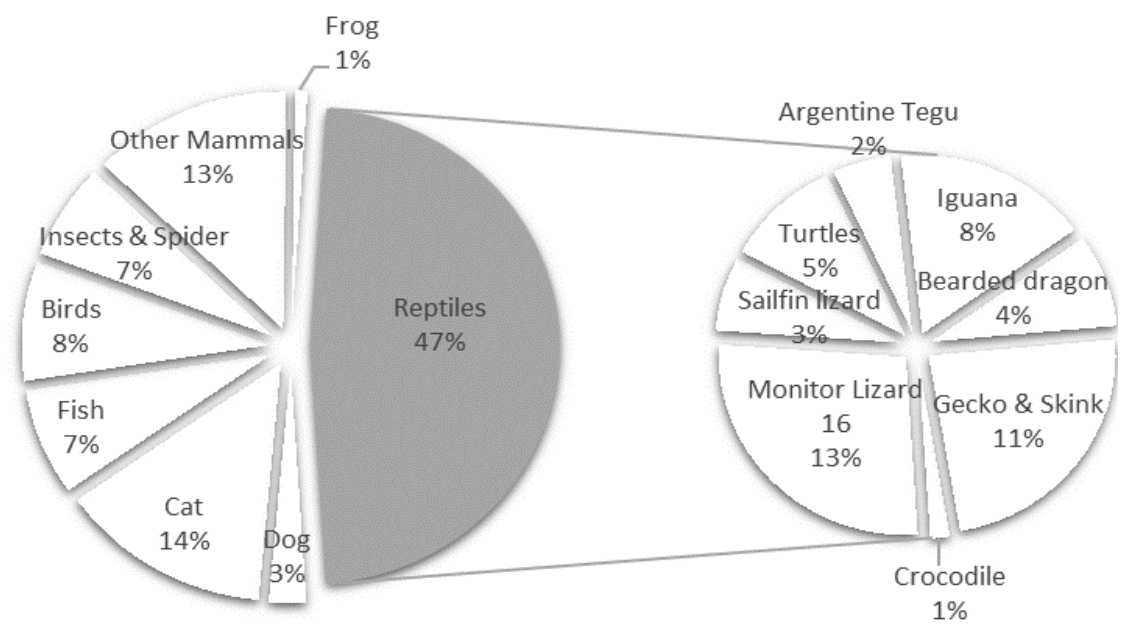

Figure 2. Animals other than snakes being kept as pets by respondents in Greater Jakarta (2019) 


\section{Snake pet characteristics}

Thirty-nine species of snake from nine families were listed as pets, of which 32 species are distributed in Indonesia. Of these, 15 species are distributed in the western part of Indonesia (Sumatra, Java, and Kalimantan), 6 species are widely distributed in western part up to Sulawesi and Lesser Sunda Island, 4 species are from eastern part of Indonesia (Moluccas and Papua), 1 species is endemic to Borneo, and 5 species are also distributed in peninsular Malaysia and into Sumatra. Twenty species from 8 families were listed as species selected as an initial snake pet, with the Reticulated python, Malayopython reticulatus $(\mathrm{n}=30)$ as the most frequently selected snake, followed by the Ball python (Python regius, $\mathrm{n}=10$ ), Blood python $(P$. brongersmei, $\mathrm{n}=6)$ and Sumatran short-tailed python ( $P$. curtus, $\mathrm{n}=6)$. Overall, members of the Pythonidae were the snakes most frequently selected as pets $(65.7 \%)$, followed by Colubridae (10.7\%) and Viperidae $(9.44 \%)$. The Reticulated python was the most frequently kept snake (30.5\%), followed by the Ball python (13.3\%), Blood python (6.9\%) and the Pacific ground boa (Candoia carinata) (5.6\%) (Table 3$)$.

Most of the snake owners kept non-venomous snakes (83.3\%), 12\% kept highly venomous snakes, and $4.7 \%$ kept mildly venomous snakes. Venomous species kept as pets mostly came from the snake families Viperidae, Elapidae and Colubridae. The percentage of venomous snakes kept by the owner as a first pet $(8.9 \%)$ was lower than those acquired later (20.8\%). Five species of venomous snake were kept as a first pet, compared to 16 species of venomous snake kept overall. Only a small number of owners kept snakes originating from overseas (non-Indonesian species) (18.45\%). These included seven species of snake that were from other countries, namely the Ball python (Python regius) and Africa rock python (Python sebae) from Africa, the Boa constrictor (Boa imperator) from South America, Mexican black kingsnake (Lampropeltis getula), Desert Kingsnake (L. splendida), Milksnake (L. triangulum), and Corn snake ( Pantherophis guttatus) from the USA. All imported snakes were nonvenomous species. The Ball python was the most popular imported pet snake $(13.3 \%)$, followed by the corn snake $(2.37 \%)$.

Based on their conservation status and protected species status, most of the snakes kept are listed as being of Least Concern in IUCN Red List. Only two species were listed as Vulnerable, i.e. the King cobra (Ophiophagus hannah) and the Burmese python (Python bivittatus). The Javan spitting cobra (Naja sputatrix), and all snakes from the Families Boidae and Pythonidae are listed in Appendix II of CITES. The Green tree python (Morelia viridis) and the Burmese python ( $P$. bivittatus) are protected under Indonesian law. Only $70 \%$ of the respondents forwarded information regarding the longest period of time that they had kept snakes. Of these, around $50 \%$ had kept snakes for around 1-2 years (Table 4). Only 10\% of respondents had kept snakes for more than 6 years. One respondent wrote that the longest duration he had kept a pet snake (a white-lipped green viper) (T. albolabris) was one he had kept since he was in $6^{\text {th }}$ grade until $12^{\text {th }}$ grade, at the time of survey.
Two-thirds $(60.1 \%)$ of the snakes had been purchased, mostly from online shops $(30.77 \%)$, from friends $(28.85 \%)$ and a small percentage from pet shops. Others cited different sources, $12.82 \%$ of the owners said that their snakes came from the wild, and $2.56 \%$ of the snakes were rescued (Table 5). The monthly maintenance costs of keeping snakes ranged from IDR 100,000 to IDR 1 million (USD 7-70). Most of the respondents (55\%) gave their monthly expenditure for keeping snakes as a maximum of IDR 100,000.00 (USD 7), whereas $37.7 \%$ had a monthly expenditure between IDR 100,000 and IDR 500,000 (USD 7 -35). Most expenditure went on the purchase of food, and for routine checks to the vet. However, $77 \%$ of respondents never brought their snake to a vet. Knowledge about the care for snakes came from various sources, mostly from a combination of sources: friends, snake owners' groups, vets, internet, and sellers.

\section{Knowledge and perception about the conservation of snakes}

When respondents were asked whether it was alright to take snakes from the wild to keep as pets, $16 \%$ agreed. Those who agreed gave several reasons, i.e. hobbies, educational reasons, only taking non - protected species, and lastly, some said it is better than the snake being harvested for its skin. Those who disagreed mostly cited the reason that wildlife belongs in the wild, for the sake of a balanced ecosystem, and several mentioned the fact that wild-caught snakes are usually more prone to stress and die quickly, or harm people.

Most people had heard about protected species (91.2\%), but when further asked to list the names of protected species, $46 \%$ out of 50 people wrote the wrong names. These were written as "albertisi", "molurus" "sanca batik", "king cobra" or just "all Papuan snake". When asked to give reasons why a species needs to be protected, around $2 / 3$ of respondents $(60.6 \%)$ said that it was because populations in the wild have declined, and others gave reasons related to habitat, i.e. destroyed habitat and endemicity (= restricted range), and population declines such as high hunting pressures or illegal harvesting.

\section{Discussion}

The results show that snakes have become increasingly popular as pets, especially for young people. Jakarta youngsters have always been considered as trendsetters for Indonesian youths elsewhere (Sarwono 2013), thus the trend of keeping exotic animals in Jakarta might easily be followed by others living in other areas of Indonesia. It is not known whether gender affected the choice of pets. The higher number of males as respondents is similar to the findings of Vucinic et al (2019) that in the Balkans, more males own reptiles than females.

Although the motivation to keep snakes came mostly from the behavior of their peers, a number of people were motivated to keep snakes based on what they had seen in social media. There are no reports on the extent of the impact of social media as an initiator of snake ownership, but a glance at the profiles of followers on social media (e.g. Facebook and Instagram) shows that there are several 
groups that are dedicated to snake owners in Indonesia. For instance, a popular Indonesian 'You Tuber' that specializes in his content mostly about snakes goes under the name of Panji Petualang, and he has more than 8 million subscribers. Social media can potentially act as a means of increasing public awareness about the conservation of wild animals (Waters and El-Harrad 2013; Wu et al. 2018), but on the other hand, it can also have a negative impact by encouraging the collection of animals from the wild
(Siriwat and Nijman 2018; Spee et al. 2019). More research needs to be conducted on how social media acts as a driver for popularizing snake ownership in Indonesia.

The popularity of snakes as pets compared to other groups of reptiles has been shown by other studies, e.g. in Brazil (Alves et al. 2019) and Japan (Wakao et al. 2018). Daniel (2011) reported that Papuan snakes (Morelia spp.) were also popular reptiles for the pet trade, which agrees with a report by Natusch and Lyons (2012).

Table 3. Snake species kept as pets in the Greater Jakarta Area, Indonesia (n respondents $=69$ ) in 2019.

\begin{tabular}{|c|c|c|c|c|c|}
\hline Species & English Name & Venom & CITES & Distribution & Choice \\
\hline \multicolumn{6}{|l|}{ Acrochordidae } \\
\hline Acrochordus granulatus & Little file snake & Non & Non App & Indonesia & $1^{\text {st }}$ snake \\
\hline \multicolumn{6}{|l|}{ Boidae } \\
\hline Boa imperator & Boa constrictor & Non & II & Colombia & $1^{\text {st }}$ snake \\
\hline Candoia carinata & Pacific ground boa & Non & II & Indonesia & $1^{\text {st }}$ snake \\
\hline \multicolumn{6}{|l|}{ Colubridae } \\
\hline Ahaetulla mycterizans & Malayan green whipsnake & Mild & Non App & Indonesia & \\
\hline Ahaetulla prasina & Asian vine snake & Mild & Non App & Indonesia & $1^{\text {st }}$ snake \\
\hline Boiga dendrophila & Banded Mangrove cat snake & Mild & Non App & Indonesia & \\
\hline Boiga multomaculata & Many-spotted cat snake & Mild & Non App & Indonesia & \\
\hline Coelognathus radiatus & Radiated ratsnake & Non & Non App & Indonesia & $1^{\text {st }}$ snake \\
\hline Gonyosoma oxycephalum & Arboreal rat snake & Non & Non App & Indonesia & \\
\hline Lampropeltis getula & Mexican black kingsnake & Non & Non App & USA & \\
\hline Lampropeltis splendida & Desert kingsnake & Non & Non App & USA & \\
\hline Lampropeltis triangulum & Milksnake & Non & Non App & USA & \\
\hline Oligodon octolineatus & Striped kukri snake & Non & Non App & Indonesia & \\
\hline Pantherophis guttatus & Corn snake & Non & Non App & USA & $1^{\text {st }}$ snake \\
\hline Ptyas korros & Indo-Chinese rat snake & Non & Non App & Indonesia & \\
\hline Rhabdophis subminiatus & Red-necked keelback & High & Non App & Indonesia & \\
\hline Xenochrophis vittatus & Striped keelback & Mild & Non App & Indonesia & $1^{\text {st }}$ snake \\
\hline \multicolumn{6}{|l|}{ Elapidae } \\
\hline Bungarus candidus & Malayan krait & High & Non App & Indonesia & \\
\hline Naja sputatrix & Javan spitting cobra & High & II & Indonesia & $1^{\text {st }}$ snake \\
\hline Ophiophagus hannah* & King cobra & High & II & Indonesia & \\
\hline \multicolumn{6}{|l|}{ Homalopsiidae } \\
\hline Enhydris enhydris & Rainbow Water Snake & Non & Non App & Indonesia & \\
\hline \multicolumn{6}{|l|}{ Pareidae } \\
\hline Pareas carinatus & Keeled slug-eating snake & Non & Non App & Indonesia & \\
\hline \multicolumn{6}{|l|}{ Pythonidae } \\
\hline Leiopython albertisi & White-lipped python & Non & II & Indonesia & $1^{\text {st }}$ snake \\
\hline Malayopython reticulatus & Reticulated python & Non & II & Indonesia & $1^{\text {st }}$ snake \\
\hline Morelia viridis\# & Green Tree python & Non & II & Indonesia & $1^{\text {st }}$ snake \\
\hline Python bivittatus\#* & Burmese python & Non & II & Indonesia & $1^{\text {st }}$ snake \\
\hline Python breitensteini & Borneo python & Non & II & Indonesia & $1^{\text {st }}$ snake \\
\hline Python brongersmai & Blood python & Non & II & Indonesia & $1^{\text {st }}$ snake \\
\hline Python curtus & Sumatran short-tailed python & Non & II & Indonesia & $1^{\text {st }}$ snake \\
\hline Python regius & Ball python & Non & II & Africa & $1^{\text {st }}$ snake \\
\hline Python sebae & African rock python & Non & II & Africa & \\
\hline \multicolumn{6}{|l|}{ Viperidae } \\
\hline Calloselasma rhodostoma & Malayan pit-viper & High & Non App & Indonesia & \\
\hline Trimeresurus albolabris & White-lipped pit viper & High & Non App & Indonesia & $1^{\text {st }} \mathrm{t}$ snake \\
\hline Trimeresurus insularis & Lesser Sunda pit viper & High & Non App & Indonesia & $1^{\text {st }}$ snake \\
\hline Trimeresurus puniceus & Flat-nose pit viper & High & Non App & Indonesia & \\
\hline Trimeresurus purpureomaculatus & Mangrove viper & High & Non App & Indonesia & \\
\hline Trimeresurus sumatranus & Sumatran pit viper & High & Non App & Indonesia & $1^{\text {st }}$ snake \\
\hline Tropidolaemus wagleri & Wagler's pit viper & High & Non App & Indonesia & $1^{\text {st }}$ snake \\
\hline \multicolumn{6}{|l|}{ Xenopeltidae } \\
\hline Xenopeltis unicolor & Sunbeam snake & Non & Non App & Indonesia & $1^{\text {st }}$ snake \\
\hline
\end{tabular}

Note: * species listed as vulnerable in the IUCN Red List, \# species protected in Indonesia 
Table 4. The length of time that various snake species had been kept by respondents in the Greater Jakarta area (2019)

\begin{tabular}{|c|c|c|c|c|}
\hline Species & $\begin{array}{c}<1 \\
\text { year }\end{array}$ & $\begin{array}{c}1-2 \\
\text { years }\end{array}$ & $\begin{array}{c}3-5 \\
\text { years }\end{array}$ & $\begin{array}{c}>6 \\
\text { years }\end{array}$ \\
\hline Boa imperator & & 1 & & \\
\hline Candoia carinata & 1 & & 1 & \\
\hline Gonyosoma oxycephala & 1 & & & \\
\hline Malayopython reticulatus & 1 & 11 & 3 & 3 \\
\hline Pantherophis guttatus & & & 1 & \\
\hline Python bivittatus & & 1 & 2 & \\
\hline Python brongersmai & 1 & 3 & 1 & \\
\hline Python regius & 1 & 8 & 2 & 1 \\
\hline Python sebae & & & 1 & \\
\hline Trimeresurus albolabris & & & & 1 \\
\hline Trimeresurus insularis & & 1 & & \\
\hline Trimeresurus puniceus & 1 & & 1 & \\
\hline Tropidolaemus wagleri & & 1 & & \\
\hline Total & 6 & 26 & 12 & 5 \\
\hline
\end{tabular}

Table 5. Sources of snakes as pets in the Greater Jakarta area (2019) based on percentage $(n=156)$

\begin{tabular}{lc}
\hline \multicolumn{1}{c}{ Source } & $\%$ \\
\hline Purchase from online shop (including auction & 30.77 \\
from social media) & \\
Purchase from friends & 28.85 \\
Gift & 17.95 \\
Taken from the wild & 12.82 \\
Purchase from petshop & 4.48 \\
Rescued snake & 2.56 \\
Captive breeding & 2.56 \\
\hline
\end{tabular}

However, our study results show that the most popular snake pets were mostly of non-Papuan origin, nonprotected and listed as being of Least Concern in the IUCN Red List. Malayopython reticulatus, the most common snake kept as a pet, is also the snake most commonly found in the western to central part of Indonesia (Stuart et al. 2018). Its habitat is not only restricted to forested areas, but it also occurs in urban areas (Rusli 2016). This snake is also harvested for its skin, and its biology and ecology are considered to be able to withstand current harvesting levels (Shine et al 1998, 1999).

The number of snake species kept as pets might be significantly higher than reported in this paper particularly if the percentages of imported snakes are included. For instance, Daniel (2011) reported 35 species of snake in the pet markets and animal markets in Jakarta, of which 18 species were imported. The most disturbing finding was the growing popularity of keeping highly venomous snakes as pets, even for 1 st snake keepers who might start keeping these snakes in their early teens. Keeping reptiles, including pets, needs to take two considerations into account, namely animal, and human welfare (Pasmans et al. 2017). A poor understanding of animal welfare can lead to injuries to the animal and its eventual mortality during captivity (Robinson et al. 2015). A poor understanding of snake behavior can lead to injuries or even death of the owner ( $\mathrm{Ng}$ et al. 2018). Besides, watching people playing with snakes on social media might attract some people (especially young ones) to play with snakes (including venomous ones). Because they may have little or no knowledge about the snakes they are often free-handling, sometimes bitten, and there have been fatalities. In the guidelines for the management of snakebites, the WHO (2016) has warned that "Displays by performers such as Austin Stevens and the late Steve Irwin on TV and social media have encouraged people to risk pursuing, attacking and handling wild snakes". There are no data on the number of injuries caused by snake pets in Indonesia, but a short search of online media has shown several cases of snake owner deaths, either by strangulation by pythons (Purba 2018; Ul Haq 2019) or being bitten by venomous snakes (Damanik 2018; Yandiputra 2019).

Snakebite envenoming is considered a global burden but is a neglected disease in many countries (Gutiérrez et al. 2006; Kasturiratne et al. 2008), including in Indonesia (Adiwinata and Nelwan 2015). There is only one antivenom available which is a polyvalent antivenom for the treatment of bites from the Javan spitting cobra (Naja sputatrix), the Banded krait (Bungarus fasciatus) and the Malayan pit viper (Calloselasma rhodostoma) (Tan et al. 2016). Pet owners who suffer venomous bites from these three species and other species for which there is no antivenom may risk the possibility of serious injuries or death. Snakebite treatment in Indonesia is still poorly understood by the medical profession, leading to ineffective or inappropriate snakebite management in medical facilities (Ardiwinata and Nelwan 2015).

Most of the snakes being kept for pets and listed in our study, are legal and listed as unprotected. Only a small number of the owner-listed species is protected by Indonesian law (M. viridis and $P$. bivittatus). There is a possibility that some respondents hid information because they were keeping protected species. Animals protected under Indonesian law PP no 7/1999 (PRI 1999) cannot be taken from the wild except for research and captive breeding. The list of protected species can be seen in PP 20/2018 (KLHK 2018). However, Indonesian Law number 8 or PP $8 / 1999$ (PRI 1999) states that wild animals from captive breeding results, or from the wild with further regulation, can be kept for recreational purposes. Thus, snakes that some owners have taken from the wild or as rescues, are quite legal to keep. Regulations covering the keeping of wild animals are unavailable until now. With a lack of wild population data, regulations continue to create problems of overharvesting in some species, especially for birds (Harris et al. 2017; Rentschlar et al. 2018). Other countries have developed licensing systems for sellers i.e. in Britain (Elwin et al. 2020), and/or for owners i.e. the Federal State of New South Wales in Australia (NSW Government 2012). In Indonesia, reptile traders, especially for the export market, are regulated by the Ministry of Environment and Forestry. The Indonesian Institute of Sciences (LIPI), as the scientific authority with the Ministry of Forestry and Environment, sets annual quotas 
for harvest and export of wildlife (Amir et al. 1998). Although the system is fairly good for managing the export of wildlife, it is not sufficient for managing the domestic trade of wildlife. In addition, internet sales sites have become an alternative place for wildlife trade, both legal and illegal (Siriwat and Nijman 2018; Nijman et al. 2019; $\mathrm{Xu}$ et al. 2020). Because of the relative ease of internet sales, actual shops are no longer needed to conduct this trade, so there is almost no regulation whatsoever. Private individuals might easily become sellers. None of the snake owners in the survey cited keeping and breeding snakes for monetary gain, but there is a distinct possibility that some might also act as breeders and sellers, as a few of the respondents had more than 20 snakes. Based on our survey results, a third of respondents bought the snakes from online shops, and a few also remarked that the species kept by them were actually specialized snake morphs. Some of the commonly-kept snakes are specifically bred to obtain various colors or morphs, and the value for these is significantly higher than for 'regular 'wild-caught snakes (Daniel 2011).

Most of the respondents said they understood why a particular species needs to be protected and they were also aware that owning protected species is illegal. It is not known where the respondents got the information from regarding population declines, but the fact that half of the respondents wrote the wrong names for protected species shows a lack of knowledge, and is, therefore, a cause for concern. Besides, their knowledge about snake identification, biology and husbandry seem to be mostly transferred by word of mouth rather than from serious study.

Grant et al. (2017) commented that although some species of reptiles and amphibians are considered as "easy" animals to keep, there is no hard evidence that this is true, thus reptiles and amphibians should not be recommended to be kept as pets, until prospective keepers learn more about their biology and husbandry before making a purchase. There are two reasons why there are concerns regarding the keeping of reptiles as pets. First, the possibility that some might be released and become invasive species (Stringham and Lockwood 2018). The reticulated python from South Sumatra, for instance, has been known to attain more than $6 \mathrm{~m}$ in length, and $75 \mathrm{~kg}$ in weight (Shine et al. 1998), and maybe released once they reach an unmanageable size (e.g. over $3 \mathrm{~m}$ ). Pet snakes that escape or are deliberately released may have significant ecological consequences and become invasive species (Lockwood et al. 2019). It is possible that released snakes might have significant negative impacts on natural ecosystems and lead to social consequences because snakes are considered dangerous by most people (Öhman and Mineka 2003). Secondly, reptiles could also pose a health hazard for owners as they are prone to carrying zoonotic pathogens (Ebani 2017). As discussed previously, health hazards also include snake bites and envenomation.

The fact that it is currently easy to obtain a snake and other species of reptile in Indonesia shows that there is a good argument for regulating reptile keeping in Indonesia. At present, there is no system of licensing available in
Indonesia to regulate the keeping of wild animals as pets. It is also worth noting that many owners do not restrict themselves to owning one group of wild animals (e.g. reptiles) as pets, but tend to keep other species as well. This may lead to further increases in over-harvesting wild species from nature.

Considering that keeping snakes might be potentially harmful to their owners or others around them, a licensing system would ensure that owners would increase safety by having at least a basic understanding of snake handling, such as keeping snakes in suitable, safe enclosures. For example, licensing systems are already available in several countries in Britain and Australia (NSW Government 2012; Elwin et al 2020). Licenses could be split into various levels, based on the requirements of husbandry of the animal and safety. Permits for the keeping of dangerous snakes should also be given based on age and experience of the owner, where high venomous snakes can only be owned by adults who have demonstrated their ability to keep less dangerous snakes for several years. Training can be given so that all of the requirements of a license are covered and fulfilled by a potential keeper before they are allowed to keep a certain potentially dangerous species. The qualifications of those giving the training would also need to be established. This systematic approach would oblige all potential keepers of snakes and other animals to learn good husbandry and safety practices before they can apply for a keeper's license, and encourage them to become more aware of the consequences of taking species from the wild.

In conclusion, this study shows that a high number of snake species, both native and exotic, are used as pet. Although most of the snake kept as pet is non-venomous, the number of venomous snakes being kept raised concern especially due to the lack of anti-venom and low understanding of snakebite treatment. Pet snake ownership in Jakarta and its surrounding area, is expected to grow in the future. There is a need to conduct similar studies in other big cities in Indonesia to get the overall pictures of snake ownership, especially to develop a regulation for snake keeping in Indonesia.

\section{ACKNOWLEDGEMENTS}

We thank Perkumpulan Penggalang Herpetologi Indonesia (Herpetological Society of Indonesia) for its intermediary role which enabled us to gain information regarding snake ownership. Discussions with Ron Lilley have improved this manuscript tremendously, and we appreciate the time and inputs given to us.

\section{REFERENCES}

Adiwinata R, Nelwan EJ. 2015. Snakebite in Indonesia. Acta Med Indones 47: 358-365. PMID: 26932707.

Alves RRN, de Araújo BMC, da Silva Policarpo I, Pereira HM, Borges AKM, da Silva Vieira WL, Vasconcellos A. 2019. Keeping reptiles as pets in Brazil: Ethnozoological and conservation aspects. J Nat Conserv 49: 9-21. DOI: 10.1016/j.jnc.2019.02.002. 
Amir M, Sugardjito J, Boeadi. 1998. The scientific authority of CITES, the Indonesian Institute of Science, LIPI. In: Erdelen W (eds) Conservation, Trade and Sustainable Use of Lizards and Snakes in Indonesia. Mertensiella, Rheinbach.

Auliya M. 2003. Hot trade in cool creatures: A review of the live reptile trade in the European Union in the 1990s with a focus on Germany. Traffic Europe, Brussels. DOI: 10.13140/RG.2.1.2341.0728.

Auliya M, Altherr S, Ariano-Sanchez D, Baard EH, Brown C, Brown RM, Cantu J-C, Gentile G, Gildenhuys P, Henningheim E, Hintzmann J, Kanari K, Krvavac M, Lettink M, Lippert J, Luiselli L, Nilson G, Nguyen TQ, Nijman V, Parham JF, Pasachnik SA, Pedrono M, Rauhaus A, Córdova DR, Sanchez M-E, Schepp U, van Schingen M, Schneeweiss N, Segniagbeto GH, Somaweera R, Sy EY, Türkozan O, Vinke S, Vinke T, Vyas R, Williamson S, Ziegler T. 2016. Trade in live reptiles, its impact on wild populations, and the role of the European market. Biol Conserv 204: 103-119. DOI: 10.1016/j.biocon.2016.05.017.

Damanik C. 2018. Rizky was killed by the king cobra he helped during the flood. Kompas.com. https://regional.kompas.com/read/2018/07/10/19470961/rizky-tewasdipatuk-ular-king-kobra-yang-ditolongnya-saat-banjir?page=all. 12 December 2020. [Indonesian]

Daniel S. 2011. Trade of Reptiles as Pets in DKI Jakarta. [Hon. Thesis]. Institut Pertanian Bogor, Bogor. [Indonesian]

Ebani VV. 2017. Domestic reptiles as source of zoonotic bacteria: A minireview. Asian Pacific $\mathrm{J}$ Trop Dis 10: 723-728. DOI 10.1016/j.apjtm.2017.07.020

Elwin A, Green J, D'Cruze N. 2020. On the record: An analysis of exotic pet licenses in the UK. Animals 10: 2373 - 2405 DOI: $10.3390 /$ ani10122373.

Engler M, Parry-Jones R. 2007. Opportunity or Threat: The Role of the European Union in Global Wildlife Trade. Traffic Europe, Brussels.

Grant R, Montrose V, Wills A. 2017. ExNOTic: Should we be keeping exotic pets? Animals 7: 47-57. DOI:10.3390/ani7060047.

Gutiérrez JM, Theakston RDG, Warrell DA. 2006. Confronting the neglected problem of snakebite envenoming: The need for a global partnership. PLoS Med 3: 727-731. DOI: 10.1371/journal.pmed.0030150.

Harris JBC, Tingley MW, Hua F, Yong DL, Adeney JM, Lee TM, Marthy W, Prawiradilaga DM, Sekercioglu CH, Suyadi, Winarni N, Wilcove DS. 2017. Measuring the impact of the pet trade on Indonesian birds: Bird declines from pet trade. Conserv Biol 31: 394-405. DOI: 10.1111/cobi.12729.

Hasibuan HS, Soemardi TP, Koestoer R, Moersidik S. 2014. The role of transit-oriented development in constructing urban environmental sustainability, the case of Jabodetabek, Indonesia. Procedia Environ Sci 20: 622-631. DOI: 10.1016/j.proenv.2014.03.075.

Herrel A, van der Meijden A. 2014. An analysis of the live reptile and amphibian trade in the USA compared to the global trade in endangered species. Herpetol Rev 24: 103-110.

Kasturiratne A, Wickremasinghe AR, de Silva N, Gunawardena NK, Pathmeswaran A, Premaratna R, Savioli L, Lalloo DG, de Silva HJ. 2008. The global burden of snakebite: A literature analysis and modelling based on regional estimates of envenoming and deaths. PLoS Med 5: e218. DOI: 10.1371/journal.pmed.0050218.

[KLHK] Kementerian Lingkungan Hidup dan Kehutanan. 2018. Regulation of the Minister of Environment and Forestry Number P.20/MENLHK/SETJEN/KUM.1/6/2018 regarding Protected Animal and Plant Species [Indonesian]

Lewis A, Krägeloh CU, Shepherd D. 2009. Pet ownership, attachment and health-rated quality of life in New Zealand. Electronic J Appl Psychol 5(1): 96-101. DOI: 10.7790/ejap.v5i1.138.

Lockwood JL, Welbourne DJ, Romagosa CM, Cassey P, Mandrak NE Strecker A, Leung B, Stringham OC, Udell B, Episcopio-Sturgeon DJ, Tlusty MF, Sinclair J, Springborn MR, Pienaar EF, Rhyne AL, Keller R. 2019. When pets become pests: The role of the exotic pet trade in producing invasive vertebrate animals. Front Ecol Environ 17: 323-330. DOI:10.1002/fee.2059.

Mardiastuti A. 2009. Analysis and development of illegal trade vulnerability map. Directorate of Biodiversity Conservation, Ministry of Forestry, Republic of Indonesia, Jakarta. [Indonesian].

Marshall BM, Strine C, Hughes AC. 2020. Thousands of reptile species threatened by under-regulated global trade. Nat Commun 11: 47381449. DOI: $10.1038 / \mathrm{s} 41467-020-18523-4$.
McConnell AR, Brown CM, Shoda TM, Stayto LE, Martin CE. 2011. Friends with benefits: On the positive consequences of pet ownership. J Pers Soc Psychol 101(5): 1239-1252. DOI: 10.1037/a0024506.

Natusch DJD, Lyons JA. 2012. Exploited for pets: The harvest and trade of amphibians and reptiles from Indonesian New Guinea. Biodivers Conserv 21: 2899-2911. DOI: 10.1007/s10531-012-0345-8339-343.

Nijman V, Morcatty T, Smith JH, Atoussi S, Shepherd CR, Siriwat P, Nekaris KA-I, Bergin D. 2019. Illegal wildlife trade - surveying open animal markets and online platforms to understand the poaching of wild cats. Biodiversity 20: 58-61. DOI: 10.1080/14888386.2019.1568915.

$\mathrm{Ng} \mathrm{VC,} \mathrm{Lit} \mathrm{AC,} \mathrm{Wong} \mathrm{O,} \mathrm{Tse} \mathrm{M,} \mathrm{Fung} \mathrm{H.} \mathrm{2018.} \mathrm{Injuries} \mathrm{and}$ envenomation by exotic pets in Hong Kong. Hong Kong Med J 24: 48-55. DOI: $10.12809 / \mathrm{hkmj} 176984$.

NSW Government. 2012. Complete outline of the NSW reptile licensing system. www.environment.nsw.gov.au/wildlifelicences/ReptileLicensingOutli ne.

Öhman A, Mineka S. 2003. The malicious serpent: Snakes as a prototypical stimulus for an evolved module of fear. Curr Dir Psychol Sci 12(1): 5-9. DOI: 10.1111/1467-8721.01211.

Pasmans F, Bogaerts S, Braeckman J, Cunningham AA, Hellebuyck T, Griffiths RA, Sparreboom M, Schmidt BR, Martel A. 2017. Future of keeping pet reptiles and amphibians: towards integrating animal welfare, human health and environmental sustainability. Vet Rec 181: 450-450. DOI: 10.1136/vr.104296.

[PRI] Pemerintah Republik Indonesia. 1999. Indonesian Republic Government Regulation Number 7 Year 1999 on the Preservation of Plants and Animals. Ministry of State Secretariat, Jakarta. [Indonesian].

[PRI] Pemerintah Republik Indonesia. 1999. Peraturan Pemerintah Republik Indonesia Nomor 8 Tahun 1999 tentang Pemanfaatan Jenis Tumbuhan dan Satwa Liar. Sekretariat Negara, Jakarta. [Indonesian].

Polák J, Sedláčková K, Nácar D, Landová E, Frynta D. 2016. Fear the serpent: A psychometric study of snake phobia. Psychiatry Res 242: 163-168. DOI: 10.1016/j.psychres.2016.05.024.

Purba DO. 2018. A painter was killed by his pet python. Kompas online. megapolitan.kompas.com/read/2018/02/02/23162501/seorangpelukis-tewas-dililit-ular-sanca-peliharaannya. 3 February 2021. [Indonesian].

Putranto DI, Yuda P, Zahida F. 2016. Diversity of imported reptiles in Yogyakarta. Biota 1(3):117-125. [Indonesian]

Rentschlar KA, Miller AE, Lauck KS, Rodiansyah M, Bobby, Muflihati, Kartikawati. 2018. A silent morning: The songbird trade in Kalimantan, Indonesia. Trop Conserv Sci 11: 1-10. DOI: $10.1177 / 1940082917753909$.

Rusli N. 2016. Snakes of Jakarta and Its Surrounding. Ciliwung Reptile Center, Jakarta. [Indonesian].

Robinson JE, St. John FAV, Griffiths RA, Roberts DL. 2015. Captive reptile mortality rates in the home and implications for the wildlife trade. PLoS ONE 10: e0141460. DOI:10.1371/journal.pone.0141460.

Rustiadi E, Pribadi DO, Pravitasari AE, Indraprahasta GS, Iman LS. 2015. Jabodetabek Megacity: From city development toward urban complex management system. In: Singh RB (eds). Urban Development Challenges, Risks and Resilience in Asian megacities. Springer Japan, Tokyo. DOI: 10.1007/978-4-431-55043-3_22.

Sarwono S. 2013. Anak Jakarta: A sketch of Indonesian youth identity. Wacana Journal of the Humanities of Indonesia 15: 41-65. DOI: 10.17510/wjhi.v15i1.104.

Shine R, Ambariyanto, Harlow PS, Mumpuni. 1998. Reticulated pythons in Sumatra: Biology, harvesting and sustainability. Biol Conserv 87: 349-357. DOI: 10.1016/S0006-3207(98)00068-8.

Shine R, Ambariyanto, Harlow PS, Mumpuni. 1999. Ecological attributes of two commercially-harvested python species in Northern Sumatra. J Herpetol 33: 249-257. DOI: 10.2307/1565722.

Sinaga HN. 2008. Trade-in Terrestrial and Freshwater Turtles in Jakarta. [Unpublished Master Thesis]. Institut Pertanian Bogor, Bogor. [Indonesian]

Siriwat P, Nijman V. 2018. Illegal pet trade on social media as an emerging impediment to the conservation of Asian otter species. J Asia Pac Biodivers 11: 469-475. DOI: 10.1016/j.japb.2018.09.004.

Situngkir SVR. 2009. Snake trade and its traditional use in Bogor [Unpublished Bachelor Thesis]. Institut Pertanian Bogor, Bogor. [Indonesian] 
Spee LB, Hazel SJ, Grande ED, Boardman WSJ, Chaber A-L. 2019. Endangered exotic pets on social media in the Middle East: Presence and impact. Animals 9: 480-494. DOI:10.3390/ani9080480.

Stringham OC, Lockwood JL. 2018. Pet problems: Biological and economic factors that influence the release of alien reptiles and amphibians by pet owners. J Appl Ecol 55: 2632-2640. DOI: 10.1111/1365-2664.13237.

Stuart B, Thy N, Chan-Ard T, Nguyen TQ, Grismer L, Auliya M, Das I, Wogan G. 2018. 'Python reticulatus', in The IUCN Red List of Threatened Species 2018: e.T183151A1730027, viewed 11 February 2021. DOI: 10.2305/IUCN.UK.2018-2.RLTS.T183151A1730027.en.

Tan CH, Liew JL, Tan KY, Tan NH. 2016. Assessing SABU (Serum Anti Bisa Ular), the sole Indonesian antivenom: A proteomic analysis and neutralization efficacy study. Sci Rep 6: 1-10. DOI: 10.1038/srep37299.

Uetz P, Freed P, Hošek J. 2017. The reptile database. www.reptiledatabase.org.

Ul Haq MF. 2019. The domesticated python kills its master in Bandung, the Ministry of Environment and Forestry will check the permit. Detik Online. https://news.detik.com/berita/d-4597339/ular-sancapeliharaan-tewaskan-tuannya-di-bandung-klhk-akan-cek-izin 24 June 2019. [Indonesian]
Vucinic M, Hajzler I, Terzin J, Radisavljevic K, Jankovic L, Voslarova E, Vucicevic M. 2019. Reptile ownership in Balkan Countries: demographics and reliance on veterinary advice. Anthrozoös 32: 129139. DOI: 10.1080/08927936.2019.1550287.

Waters S, El-Harrad A. 2013. A note on the effective use of social media to raise awareness against the illegal trade in Barbary macaques. Afr Primates 8: 67-68.

Wakao K, Janssen J, Chng S. 2018. Scaling up: The contemporary reptile pet market in Japan. Traffic Bull 30: 28-35.

World Health Organization [WHO]. 2016. Guidelines for the Management of Snakebites. WHO Regional Office for South-east Asia, New Delhi.

Wu Y, Xie L, Huang S-L, Li P, Yuan Z, Liu W. 2018. Using social media to strengthen public awareness of wildlife conservation. Ocean Coast Manag 153: 76-83. DOI: 10.1016/j.ocecoaman.2017.12.010.

Xu Q, Cai M, Mackey TK. 2020. The illegal wildlife digital market: An analysis of Chinese wildlife marketing and sale on Facebook. Environ Conserv 47(3):1-7. DOI: 10.1017/S0376892920000235.

Yandwiputra AR. 2019. A recently online bought King cobra bit and killed its owner. Tempo Online. metro.tempo.co/read/1270996/kingcobra-patuk-dan-tewaskan-pemiliknya-baru-dibeli-online. December 2020. [Indonesian]. 